\title{
Froin's syndrome associated with spinal tuberculosis
}

\author{
Kripa Maharjan, ${ }^{1}$ Sudeep Adhikari, ${ }^{2}$ Buddha Basnyat ${ }^{3}$
}

${ }^{1}$ Patan Academy of Health Sciences, Kathmandu, Nepal ${ }^{2}$ Department of Internal Medicine, Patan Hospital, Kathmandu, Nepal ${ }^{3}$ Oxford University Clinical Research Unit, Patan Hospital, Kathmandu, Nepal

\section{Correspondence to}

Professor Buddha Basnyat, buddhabasnyat@gmail.com

Accepted 30 November 2018

\section{DESCRIPTION}

A 25-year-old male patient from Sarlahi district in Southern Nepal presented to the emergency department of Patan Hospital in Kathmandu, Nepal with an inability to move both lower limbs for 8 days. Prior to this, he had a low-grade fever, dry cough, decreased appetite, weight loss and tingling sensation on the lower limbs for 3 months. He was diagnosed with sputum-positive pulmonary tuberculosis (TB) 1 month ago and category 1 antitubercular therapy (ATT) was started with daily three tablets of HRZE, each containing 75 mgisoniazid $(\mathrm{H}), 150$ $\mathrm{mg}$ rifampicin $(\mathrm{R}), 400 \mathrm{mg}$ pyrazinamide $(\mathrm{Z})$ and $275 \mathrm{mg}$ ethambutol (E) but as fever subsided, he stopped taking the ATT after about 10 days. Ten days later after stopping his medicines, he developed an inability to move his lower limbs and had urinary retention in addition.

Nervous system examination revealed a spastic type of paraplegia with bilateral upgoing plantar reflexes and exaggerated lower limb deep tendon reflexes. Other examinations were normal.

Lumbar puncture revealed xanthochromic cerebrospinal fluid (CSF) which coagulated within

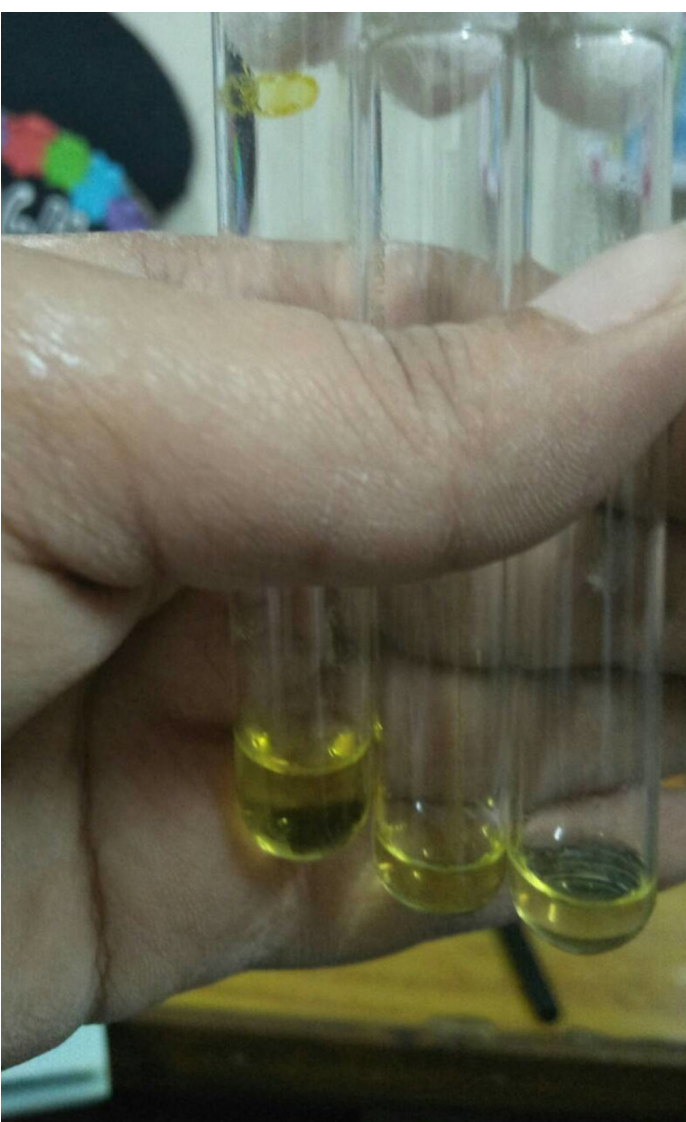

Figure 1 Xanthochromic cerebrospinal fluid.

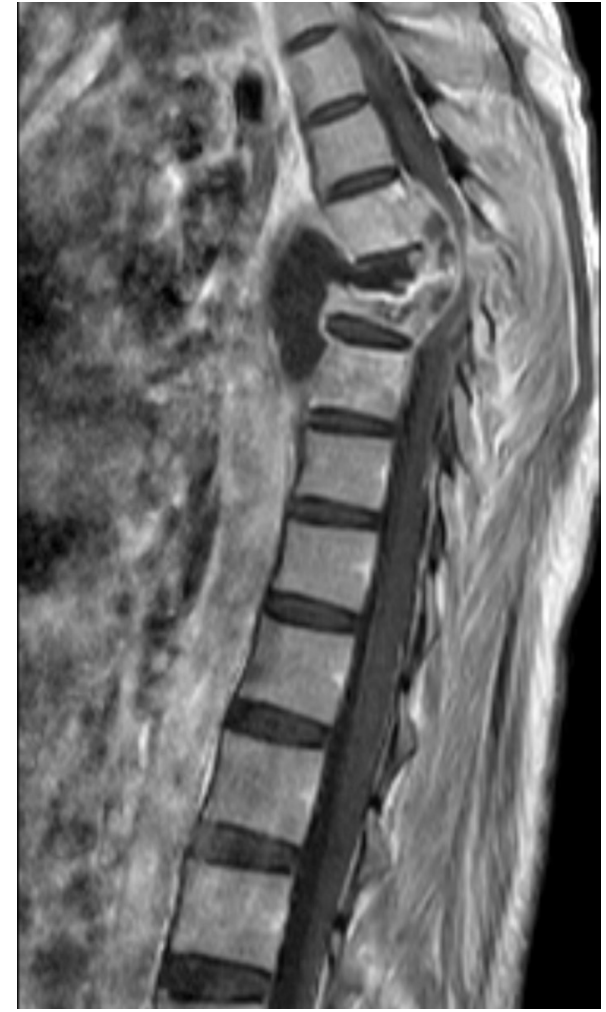

Figure $2 \mathrm{MRI}$ of a thoracic spine showing compression of T7 and T8 vertebrae along with discitis at T7-T8 level, prevertebral abscess extending from T6 to T9 level, and contrast enhancing soft-tissue density (epidural abscess) in the anterior aspect of cord from T6 to T8, compressing the spinal cord.

an hour while awaiting for laboratory analysis (figure 1). Blood counts could not be done, but the protein level was more than $1500 \mathrm{mg} / \mathrm{dL}$. This triad (CSF xanthochromia, hypercoagulability and very high protein count) was first described by Froin, a French physician. ${ }^{1}$ This classic combination has been termed Froin's syndrome. It occurs with blockage of CSF flow by a spinal cord mass such as a tumour or with meningeal irritation from inflammation. $^{2}$ Distal to the block stagnation of CSF occurs leading to higher protein transudation, and resulting xanthochromia (due to bilirubin binding to albumin) and hypercoagulability (due to high fibrinogen level). ${ }^{3}$

The presence of paraplegia in the setting of pulmonary TB prompted us to consider Pott's paraplegia in our patient, and also the possibility of some obstructive cord lesion was considered due to the presence of Froin's syndrome. MRI was suggestive of Pott's spine with the presence of spondylitis at thoracic T3-T9 vertebrae, compression of T7 and T8 vertebrae along with discitis at T7-T8 level, 
prevertebral abscess extending from T6 to T9 level, and contrast enhancing soft-tissue density in the anterior aspect of cord from T6 to T8, compressing the spinal cord, suggestive of tuberculous epidural abscess (figure 2). This explained the presence of Froin's syndrome in our patient with Pott's spine.

He was restarted on ATT. The abscess was drained. On follow-up after 2 weeks of discharge, he had marked improvement in his paraplegia, though still unable to function independently.

The importance of reporting about Froin's syndrome is that its presence in our patient prompted us to think of some obstructive

\section{Learning points}

- Pott's spine usually takes the form of spondylodiscitis leading to paraplegia, and sometimes can develop epidural abscess compressing the spinal cord and the central cerebrospinal fluid (CSF) canal.

- Yellow and hypercoagulable CSF with high protein is a classic triad called Froin's syndrome.

- The presence of Froin's syndrome should prompt us to think of some obstruction to CSF flow such as epidural abscess as in this case. cord lesion and hence helped to clinch the proper diagnosis with an MRI. In our part of the world, we can use this syndrome as a clue towards the diagnosis when diagnostic modalities like MRI are not available or are unaffordable.

Acknowledgements To orthopedics department, Patan Hospital for their help in patient management. To radiology department, Patan Hospital for providing MRI image.

Contributors SA conceived the write-up, KM wrote the first draft, SA and BB reviewed the manuscript, $\mathrm{KM}, \mathrm{SA}$ and $\mathrm{BB}$ took care of patient and decided the final draft.

Funding The authors have not declared a specific grant for this research from any funding agency in the public, commercial or not-for-profit sectors.

Competing interests Not required.

Patient consent Obtained.

Provenance and peer review Not commissioned; externally peer reviewed.

\section{REFERENCES}

1 Froin G. Inflammations méninge'es avec chromatique, fibrineuse et cytologique du liquide ce'phalo-rachidien. Gazette des hôpitaux, Paris 1903;76:1005-6.

2 Dancel R, Shaban M. Images in clinical medicine. Froin's Syndrome. N Engl J Med 2016;374:1076.

3 Scully FJ. Yellow spinal fluid its origin and significance. Arch Neurol Psychiatry 1923;10:83-99.

Copyright 2018 BMJ Publishing Group. All rights reserved. For permission to reuse any of this content visit

https://www.bmj.com/company/products-services/rights-and-licensing/permissions/

BMJ Case Report Fellows may re-use this article for personal use and teaching without any further permission.

Become a Fellow of BMJ Case Reports today and you can:

- Submit as many cases as you like

- Enjoy fast sympathetic peer review and rapid publication of accepted articles

- Access all the published articles

- Re-use any of the published material for personal use and teaching without further permission

For information on Institutional Fellowships contact consortiasales@bmjgroup.com

Visit casereports.bmj.com for more articles like this and to become a Fellow 